\title{
Determination of Tariff Limits for Energy and Material Resources Using National Accounts Data
}

\author{
Vitaly Postolati \\ Institute of Power Engineering, Chiisinau, Republic of Moldova
}

Email address:

vpostolati@rambler.ru

\section{To cite this article:}

Vitaly Postolati. Determination of Tariff Limits for Energy and Material Resources Using National Accounts Data. American Journal of Management Science and Engineering. Vol. 4, No. 1, 2019, pp. 8-16. doi: 10.11648/j.ajmse.20190401.12

Received: March 16, 2019; Accepted: April 26, 2019; Published: May 15, 2019

\begin{abstract}
The structure and interconnection of the main macroeconomic indicators reflected in the National Accounts of the Republic of Moldova: "Release" (R), "Intermediate Consumption" (IC), "Gross Value Added" (GVA), "Gross Domestic Product" (GDP). The place of tariffs in the general structure of economic indicators has been determined. It is shown that the tariffs for energy and other types of material resources and the costs accompanying the production cycle are in the "Intermediate Consumption" (IC) sector. It is shown that an increase in tariffs leads to a decrease (GVA) and, accordingly, a decrease in volume (GDP). It is established in a quantitative form as far as the growth of tariffs overtakes the growth of real GDP. A new methodology for setting tariff limits is given, taking into account the dynamics of real GDP growth, indicators of planned GDP growth, as well as the average annual consumer price index. On the basis of calculations and substantiations, it is concluded that tariffs should be reduced by $5.6 \%$ for natural gas, by $17.7 \%$ for electricity, and by $32 \%$ for thermal energy of the central heating system, compared to their current values. The proposed methodology and approach will contribute to the sustainable development of the economy as a whole, including the energy sector, and also take into account the tasks of further improving the state of the social sphere.
\end{abstract}

Keywords: Indicators, National Accounts, Gross Value Added, Tariffs

\section{Introduction}

One of the main indicators of the development of the country's economy is the annual gross domestic product (GDP) produced. This indicator is used in world practice when comparing the levels of economic development of various countries. In the Republic of Moldova. The National Bureau of Statistics systematically and regularly processes and publishes data on macroeconomic indicators $[1,2]$, including data on GDP.

Studies [4, 5] clearly showed the quantitative relationship of tariffs with macroeconomic indicators, in particular, with the gross domestic product (GDP).

The main factors determining the volume of GDP are the volume of " Release" (R), and the volume of "Gross Value Added" (GVA).

The volume of "Gross Value Added" (GVA) is directly dependent on the "Intermediate Consumption" (IC) in the sphere of material production.

According to the accepted definitions, the volume of
"Gross Value Added" (GVA) is defined as the difference between the volume of "Release" ( $\mathrm{R}$ and the volume of "Intermediate Consumption" (IC), i. e.

$$
\mathrm{GVA}=\mathrm{R}-\mathrm{IC}
$$

The gross value added (GVA) is the main component of the gross domestic product (GDP), which is the main economic indicator of the level of the economy and social security of the society and the state as a whole.

GDP is calculated as a sum:

$$
\mathrm{GDP}=\mathrm{GVA}+\mathrm{Tax}-\mathrm{S}
$$

where Tax - taxes on manufactured products and imports; S subsidies.

Expression (2) in view of (1) takes the form:

$$
\mathrm{GDP}=\mathrm{R}-\mathrm{IS}+\mathrm{Tax}-\mathrm{SC}
$$

As follows from expression (3), the volume of GDP is the greater, the larger the volume of "Release" (R), and the 
smaller the value of "Intermediate Consumption" (IC), an

$d$ the smaller the return of "Subsidy" (S). As for taxes, their value is regulated by the relevant government agencies, depending on the type of product (value added tax - VAT, import tax, etc.). A detailed analysis of the values of the individual components of intermediate consumption in the sphere of production is possible on the basis of intersectoral balances [3, 8, 9], as well as detailed tables of national accounts [2]. They show which and to what extent each of the sectors of the economy used the services of other branches, and in what volumes the branches themselves gave to other branches, both in physical and monetary terms.

This methodology was effectively used in the previous period, until 2014 [2]. After 2014, the National Bureau of Statistics of Moldova switched to the methodology for compiling aggregated indicators [1], which, however, made it difficult to carry out a detailed analysis. At the macroeconomic level, such opportunities have been preserved.

The purpose of this article is to present a new approach to determining the maximum allowable levels of tariffs for energy and material resources using data from economic indicators of national accounts, to bring the results of studies of changes in the levels of tariffs for natural gas, electric and thermal energy and to compare with the dynamics of changes in real GDP in the last decade in the Republic of Moldova.
Comparison of tariff growth rates with the rates of increase in real GDP makes it possible to carry out an appropriate analysis and draw conclusions as to how coordinated they are and whether they meet the requirements and conditions for ensuring sustainable development of the economy and solving social problems. First of all, it is necessary to perform an analysis of the dynamics of changes in real GDP.

\section{Data Analysis of Changes in GDP}

According to the materials of the Central Statistical Bureau, such macroeconomic indicators as GDP are expressed in current prices, in comparative prices and prices, adjusted to the base year. In the latter case, the volume of GDP is expressed in the prices of the base year, most suitable for a comparative analysis of real indicators of the economy.

The real volume of GDP for each year is determined taking into account the coefficient of deflation. When choosing one of the previous years as the base year, the GDP volume of each subsequent year is defined as private, obtained by division the cost pressure of GDP at current prices for the year in question to the total deflation coefficient relative to the base year. In this paper, 2009 was adopted as the base year for comparisons.

The main initial statistical data characterizing the change in GDP are given in Table 1 [1].

Table 1. Changes in macroeconomic indicators of the economy of the Republic of Moldova for the period 2009-2017.

\begin{tabular}{|c|c|c|c|c|c|c|c|}
\hline Years & $\begin{array}{l}\text { GDP at current } \\
\text { prices, } \\
\text { thousand lei }\end{array}$ & $\begin{array}{l}\text { Index } \\
\text { deflator, } \\
\%\end{array}$ & $\begin{array}{l}\text { Medium annual } \\
\text { consumer price } \\
\text { index, } \%\end{array}$ & $\begin{array}{l}\text { GDP in comparable prices, } \\
\text { taking into account the } \\
\text { deflator index, thousand lei } \\
(2 / 3)\end{array}$ & $\begin{array}{l}\text { Total deflator } \\
\text { index, rel. } \\
\text { units }\end{array}$ & $\begin{array}{l}\text { Real GDP in } \\
\text { prices of } 2009 \text {, } \\
\text { thousand lei }(2 / 6)\end{array}$ & $\begin{array}{l}\text { Total index of change } \\
\text { in real GDP by } 2009 \text {, } \\
\text { rel. units }\end{array}$ \\
\hline 1 & 2 & 3 & 4 & 5 & 6 & 7 & 8 \\
\hline 2009 & 72524580 & $102,2 *$ & $100,0 *$ & 70963385 & 1,022 & 70963385 & 1,0 \\
\hline 2010 & 86275377 & 111,1 & 107,4 & 77655604 & 1,1354 & 75983958 & 1,071 \\
\hline 2011 & 98772814 & 108,2 & 107,6 & 91287258 & 1,229 & 80397997 & 1,133 \\
\hline 2012 & 105480184 & 107,4 & 104,6 & 98212461 & 1,319 & 79941885 & 1,127 \\
\hline 2013 & 119532871 & 103,9 & 104,6 & 115046074 & 1,371 & 87191732 & 1,229 \\
\hline 2014 & 133481634 & 106,4 & 105,1 & 125452663 & 1,459 & 91509850 & 1,210 \\
\hline 2015 & 145753642 & 109,6 & 109,7 & 132986900 & 1,599 & 91170679 & 1,285 \\
\hline 2016 & 160814564 & 105,7 & 106,4 & 152142445 & 1,690 & 95166953 & 1,341 \\
\hline 2017 & 178880890 & 106,3 & 106,6 & 168279294 & 1,796 & 99584436 & 1,403 \\
\hline 2018 prognosis & & & & & & & \\
\hline
\end{tabular}

* According to [2].

The cited data for the period 2009-2017 shows that the volume of GDP at current prices in the Republic of Moldova increased from 72.5 billion lei to 178.8 billion lei. The value of the deflator index per year was $102-111 \%$, or 1.02-1.11 rel. units. The change in the volume of GDP in comparable prices (taking into account the annual deflator index) occurred in the range of 70.9 billion lei (in 2009) to 168.2 billion lei (in 2017).

To determine the change in the volume of real GDP, it was necessary to perform the calculation of the resulting deflator index relative to the base year, which was adopted as 2009 . The calculation was performed by multiplying the deflator index value in the current year by its net value for previous years. Table 1 shows the values of the total deflator index obtained in this way.

During the period under review, its value increased from 1.022 (in 2009) to 1,796 relative units (in 2017). Having the value of the total deflator index, it became possible to determine the volume of real GDP for each year. For each year, real GDP was calculated as the ratio of GDP in current prices to the value of the total deflator index of that year by 2009 . The real GDP calculated in this way amounted to 70.9 billion lei in 2009, and by 2017 it increased to 99.5 billion lei.

Taking the ratio of the volume of real GDP each year to its value in 2009, the change in GDP for the corresponding period is defined in relative units. Dynamics of changes in real GDP for the period 2009-2017 in relative units is shown in Figure 1. 


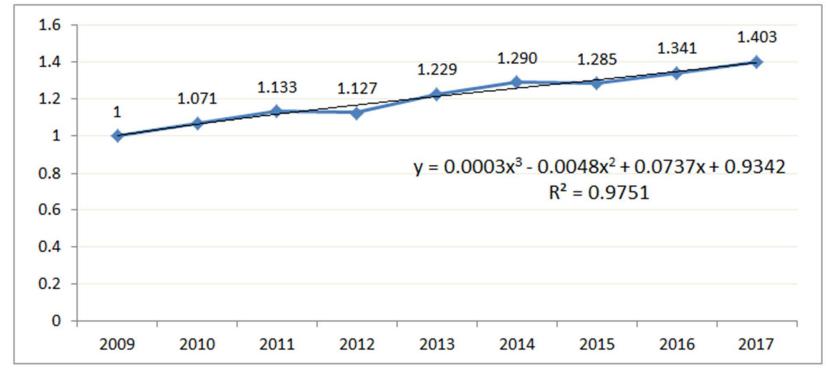

Figure 1. Growth of real GDP, relative units.

The change in real GDP ranged from 1.00 (in 2009) to 1.403 rel. units (in 2017)

The graph (Figure 1) shows an analytical expression - an equation of the line-trend of GDP change, which has the following form:

$$
\mathrm{Y}=0,0003 \cdot \mathrm{X}^{3}-0,0048 \cdot \mathrm{X}^{3}+0,0737 \cdot \mathrm{X}+0,9342,
$$

where $\mathrm{Y}$ is the real GDP value for each year (X), in relative units relative to 2009; $\mathrm{X}$ is a variable (years).

When carrying out calculations, the following values $f$ variable $(\mathrm{X})$ are accepted:

$\mathrm{X}=1-2009 ; \mathrm{X}=2-2010 ; \mathrm{X}=3-2011 ; \mathrm{X}=4-2012 ; \mathrm{X}=5$ $-2013 ; X=6-2014 ; X=7-2015 ; X=8-2016 ; X=9-2017$.

The above analytical expression (4) describes the line - the trend of real GDP change. At the same time, it makes it possible to predict the value of the expected volume of real GDP in 2018 and subsequent years. In addition, recording the expression of the first derivative $\mathrm{Y}^{\prime}(\mathrm{X})$ allows you to determine the rate of change in real GDP at any given time (X).

The expression of the first derivative of function (4) can be written in the form

$$
\mathrm{Y}^{\prime}=0,0003 \cdot 3 \mathrm{X}^{2}-0,0048 \cdot 2 \mathrm{X}+0,0737,
$$

where $\mathrm{Y}^{\prime}$ is the rate of change in the value of real GDP (Y) at any time $(\mathrm{X})$, over years, or at any other time interval.

It should be noted that if the variable $(\mathrm{X})$ is measured in years, then the derivative $\left(\mathrm{Y}^{\prime}\right)$ is nothing but indices of changes in GDP over the years in relative units. If we take the second derivative from expression (4), then the resulting new expression $\mathrm{Y}^{\prime}$ ' $(\mathrm{X})$ will determine the acceleration of changes in real GDP. In the calculations below, only the first derivative $\left(\mathrm{Y}^{\prime}(\mathrm{X})\right)$ is accepted.

Further calculations use another important indicator characterizing the social security of the population. We are talking about the average annual consumer price index (inflation index).

Based on national accounts data [1, 2], this indicator varied from 1 to 1.09 in different years. The nature of its changes over the period 2009-2017 shown in table 1 and in figure 2 . The trend line is described by the equation:

$$
\mathrm{Y}=1,0259 \cdot \mathrm{X}^{0,0213}
$$

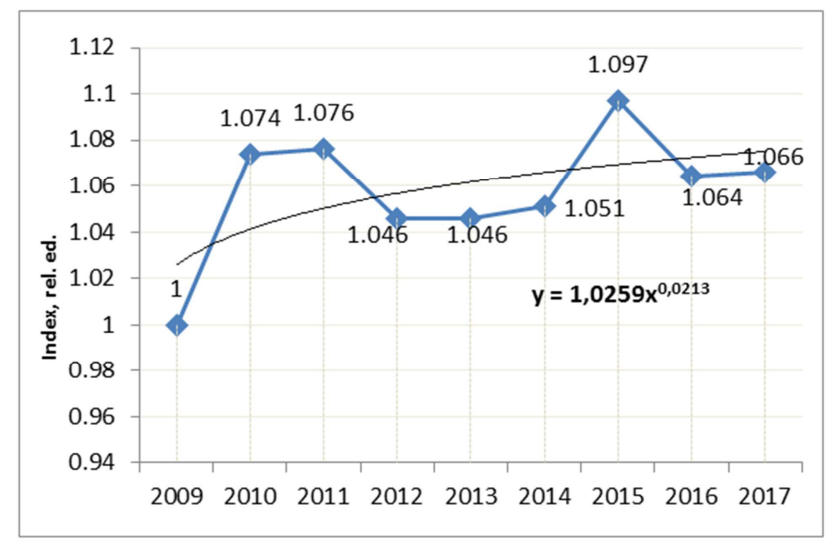

Figure 2. Change in average consumer price index, rel. units.

It was noted above that the main component of GDP is gross value added (GVA). Its value is determined according to expression (1), as the difference in the volume of "Release" (R) and volume pent "Intermediate consumption" (IC).

Volumes of "Release" and "Intermediate Consumption" according to $[1,2]$ for the period 2009-2017 re shown in table 2 .

Table 2. Data Release"and Intermediate Consumption"in the economy Of the Republic of Moldova for the period $2009-2017$ at current prices, thousand lei.

\begin{tabular}{lllll}
\hline Years & Release $(\mathbf{R})$, thousand lei & Intermediate consumption (IC), thousand lei & The ratio ofIC/ R, \% & The ratio of IC/ R, rel. units \\
\hline $\boldsymbol{1}$ & $\mathbf{2}$ & $\mathbf{3}$ & $\mathbf{4}$ & $\mathbf{5}$ \\
\hline 2009 & 127666362 & 76857170 & 60,2 \\
2010 & 149858660 & 89937970 & 60,0 \\
2011 & 168167347 & 99777789 & 59,3 & 0,602 \\
2012 & 175646560 & 101960465 & 58,04 & 0,6 \\
2013 & 196559525 & 112840049 & 57,46 & 0,593 \\
2014 & 221504229 & 127000670 & 57,33 \\
2015 & 242862568 & 138989939 & 57,22 \\
2016 & 263410750 & 147941249 & 56,16 \\
2017 & 286216970 & 131402391 & 45,91 \\
\hline
\end{tabular}

In compiling Table 2, data $[1,2]$ was used, as well as data from National Accounts for 2009-2014. As can be seen from the data given in table 2 , the value of the volume of "Intermediate consumption" (IC) in different years in the period 2009-2016 was steady amounted to $60.2 \div 57.22 \%$ of the value of the "Release". Over these years there has been a tendency to reduce the share of the volume of "Intermediate Consumption" (IC) in relation to the value of the Volume of "Release" (R) at current prices.

In 2017, the share of "Intermediate Consumption" (IC) amounted to $45.9 \%$ of the volume of "Release" (R), which is significantly lower than in previous years. 
It should be assumed that the reasons for such a significant decrease in the share of "Intermediate consumption" (IC) from the volume of "Release" (R) are a further structural adjustment of the economy of the Republic of Moldova or / and a change in the methodology for preparing and processing statistical data characterizing the main indicators of the economy of the Republic of Moldova.

The comparison of the relative indicators of 2015 and 2017 given in Table 2 is very illustrative. In 2015, with the Volume of "Release" of 242.8 billion lei, the volume of "Intermediate Consumption" amounted to 132.9 billion lei. In 2017, these values mounted to: the volume of "Release" increased to 286.2 billion lei, while the volume of "Intermediate consumption" decreased to 131.4 billion lei.

\section{Analysis of Changes in Tariffs for Major Energy Resources}

As the main energy resources are considered:

- natural gas;

- electric energy;

- thermal (heat) nergy.

The analysis of legislative acts and decisions taken by the National Energy Regulatory Agency (NARE) allowed us to determine the weighted average annual values $f$ tariffs for these types of energy resources. The data characterizing their change for the period 2009-2017 are given in figure 3-6.

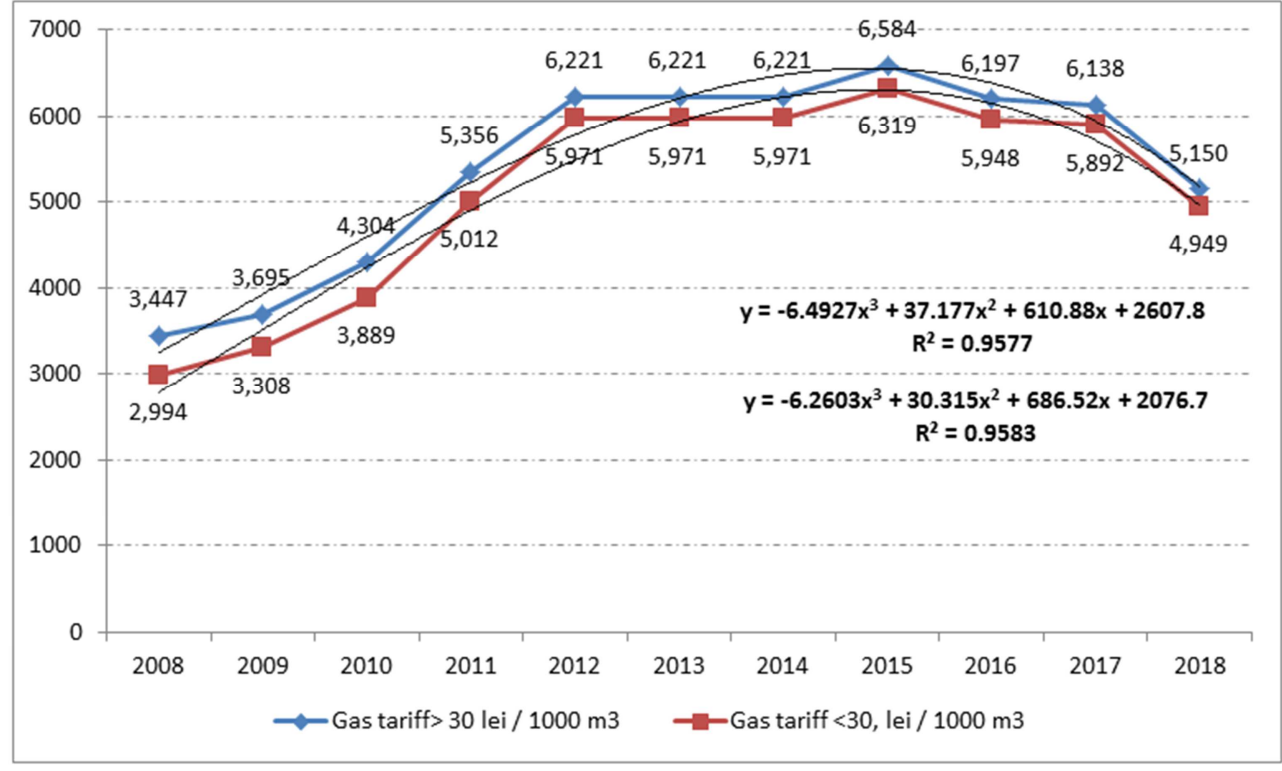

Figure 3. Natural gas Weighted Average Tariff, lei/1000 m3.

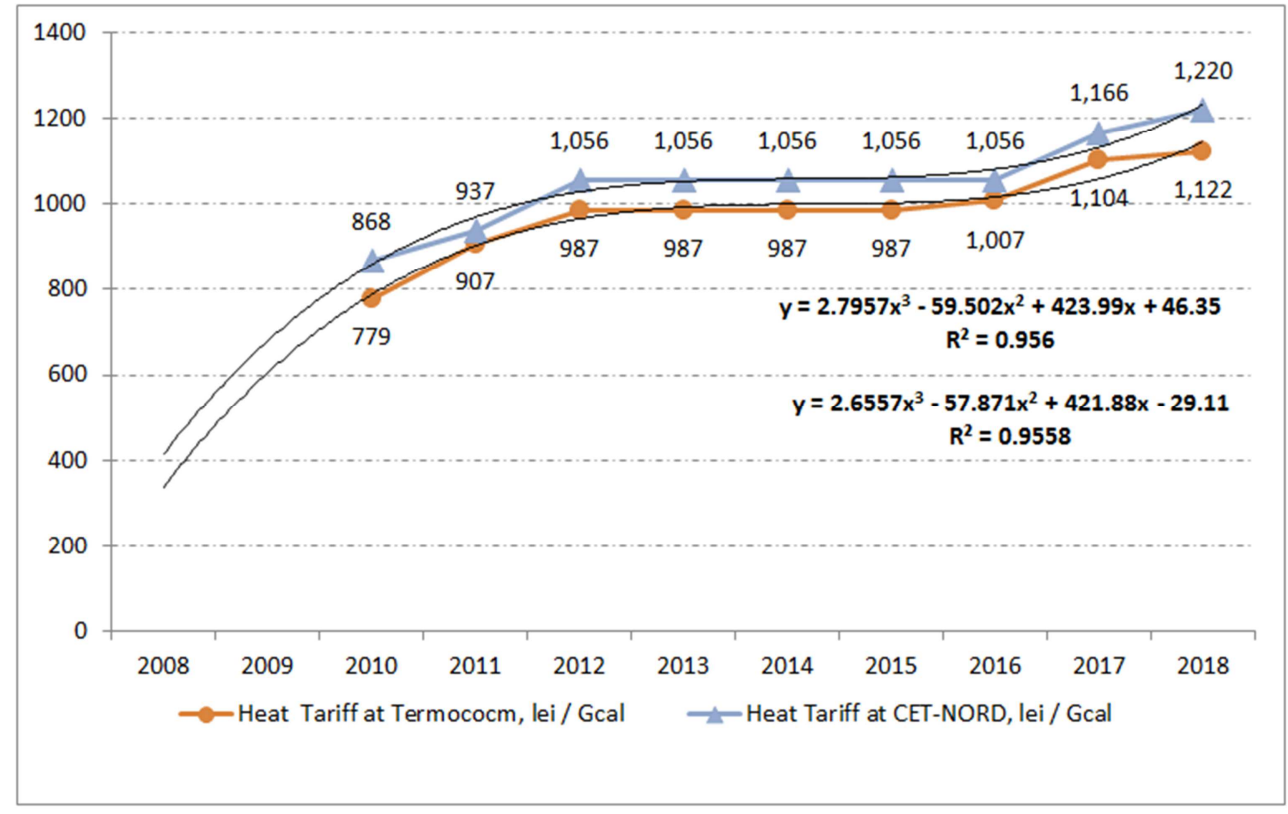

Figure 4. Heat Weighted Average Tariff, lei/Gcal. 


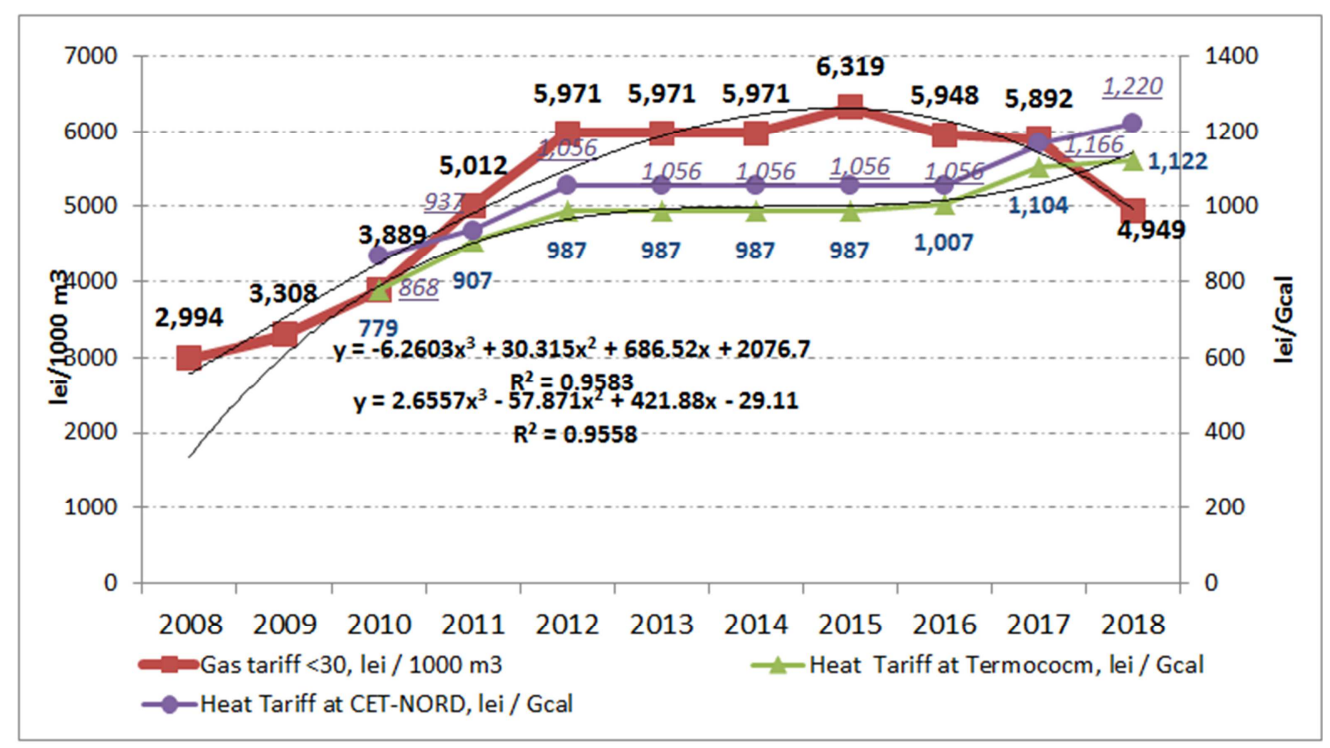

Figure 5. Natural gas Weighted Average Tariff, lei/1000 m3; Heat Weighted AverageTariff, lei/Gcal.

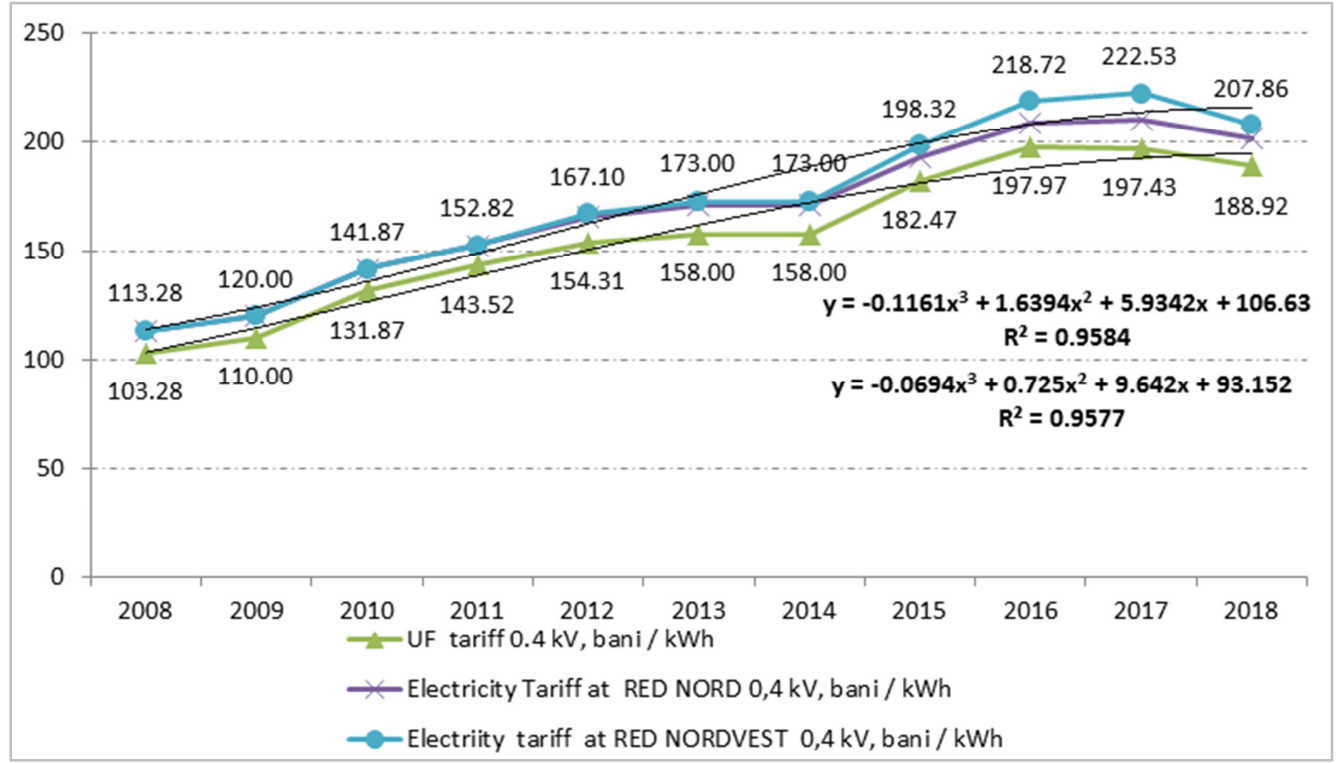

Figure 6. Electricity Weighted Average Tariff, bani/kWh.

The tariffs for natural gas increased from 2009 to 2015 from a value of 3.3 thousand lei / $1000 \mathrm{~m} 3$ (in 2009) to 6.3 thousand lei / $1000 \mathrm{~m} 3$ in 2015 (Figure 3 ). In subsequent years (2016-2018), gas tariffs decreased. In 2018, the gas tariff for consumers consuming more than $30 \mathrm{~m} 3$ - per month, 4.94 thousand lei / $1000 \mathrm{~m} 3$.

Tariffs for thermal energy in the centralized heat supply system during 2009-2017 constantly increased (Figure 4), from 540.8 lei / Gcal (in 2009 [6]) to 1122 lei / Gcal (in 2017) [10-11]. In 2018, the tariff for heat energy did not change. In figure 5, a comparison was made of the dynamics of changes in natural gas tariffs and heat energy tariffs.

In the district heating system, the main fuel for generating heat energy is natural gas. In the cost of thermal energy produced, natural gas accounts for about $80 \%$ of the total costs. Analysis of the graphs shown in Figure 5, indicates that the tariff for thermal energy in the period 2016-2018 years. not coordinated with natural gas tariff. The tariff for natural gas is reduced, and the tariff for heat energy is growing. This already has its negative consequences, both for the central heating system itself (due to the disconnection of a number of consumers and the transition to autonomous heat supply), as well as for the economy and the social sphere in general.

Tariffs for electricity for the period 2009-2017 constantly increased: from $110 \div 120 \mathrm{bani} / \mathrm{kW} \cdot \mathrm{h}$ (in 2009) to $197 \div$ 222 bani / $\mathrm{kW} \cdot \mathrm{h}$ (in 2017). In 2018, the electricity tariff was reduced to the level of $188.9 \div 207.8 \mathrm{bani} / \mathrm{kWh}$.

For an objective and visual assessment of the rate of change in tariffs and comparison with the growth rate of real GDP, it is necessary to change the tariffs in relative units for the same period as GDP, i. e. since 2009.

Estimated data of changes in tariffs for the considered resources in relative units are presented in table 3, as well as in figure 7 . 
Table 3. Indicators of changes in weighted average real tariffs for gas, heat and electricity for the period 2009-2018, in relative units in relation to 2009.

\begin{tabular}{|c|c|c|c|c|c|c|}
\hline \multirow{2}{*}{ Years } & \multicolumn{2}{|l|}{ Natural gas } & \multicolumn{2}{|c|}{ Thermal energy } & \multicolumn{2}{|l|}{ Electricity } \\
\hline & lei / $1000 \mathrm{~m} 3$ & rel. units & Lei / Gcal & rel. units & bani / kWh & rel. units \\
\hline 1 & 2 & 3 & 4 & 5 & 6 & 7 \\
\hline 2009 & 3307 & 1 & 540 & 1 & 110 & 1 \\
\hline 2010 & 3888 & 1,175 & 779,1 & 1,442 & 131,8 & 1,198 \\
\hline 2011 & 5012 & 1,515 & 906,6 & 1,678 & 143,5 & 1,304 \\
\hline 2012 & 5571 & 1,805 & 987,0 & 1,827 & 154,3 & 1,402 \\
\hline 2013 & 5971 & 1,805 & 987,0 & 1,827 & 158,0 & 1,436 \\
\hline 2014 & 5971 & 1,805 & 987,0 & 1,827 & 158,0 & 1,436 \\
\hline 2015 & 6319 & 1,91 & 987,0 & 1,827 & 182,4 & 1,658 \\
\hline 2016 & 5948 & 1,798 & 1007,1 & 1,865 & 197,9 & 1,799 \\
\hline 2017 & 5892 & 1,781 & 1104,2 & 2,044 & 197,4 & 1,794 \\
\hline 2018 & 4948 & 1,496 & 1122,0 & 2,077 & 189,9 & 1,717 \\
\hline
\end{tabular}

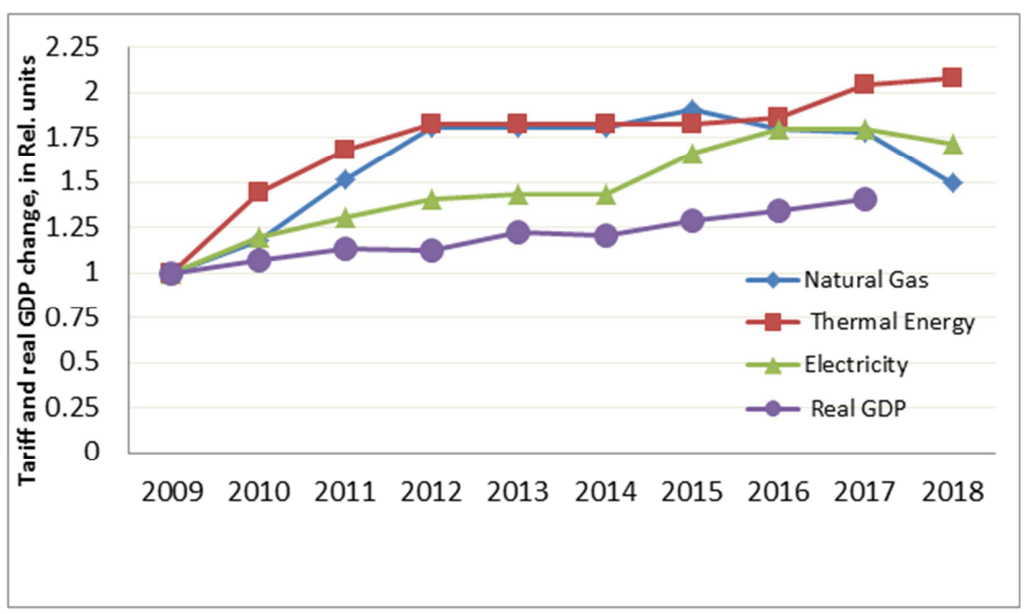

Figure 7. Changes in energy tariffs and real GDP growth for the period 2009-2018, in rel. units, in relation to 2009.

In figure 7 comparison of data on changes in energy tariffs and changes in real GDP for the period 2009-2018 in relative units. This whole period is characterized by more accelerated the rate of growth of tariffs for energy compared to the dynamics of growth in real GDP.

Tariffs for the types of energy resources in question increased particularly intensively in the period 2009-2016. With real GDP growth 1.34 times compared to 2009, the increase in tariffs at current prices was compared to 2009:

- for natural gas - 1.79 times;

- for thermal energy - 1.86 times;

- for electricity - 1.79 times.

After 2016, the situation has changed a bit, due to a decrease in the purchase price for natural gas. At the same time, the tariffs for natural gas decreased in 2018 to the level of 4948 lei / $1000 \mathrm{~m} 3$ and for electricity up to 188.9 bani / $\mathrm{kWh}$. However, as follows from Figure 7, relative tariff growth data remained higher than real GDP growth. As for heat energy, the tariff for it remained the highest, unchanged.

The analysis shows that the existing methodology for setting tariffs for energy resources does not take into account real processes in the economy and the social sphere. The fact that tariff growth rates are ahead of the dynamics of real GDP growth is a constraining factor on the path of successful economic growth and improvement of social benefits in society.
Below in the article, a method is proposed for calculating permissible levels of tariffs, based on an analysis of the dynamics of changes in real GDP, and taking into account the planned plans for economic development and improvement of the social situation.

\section{The Essence of the New Approach to Determining the Permissible Levels of Tariffs}

The main idea of the new approach is to ensure that the following conditions are met when determining the maximum allowable tariff levels: tariff growth rates $(\Delta \mathrm{T})$ should not be higher than real GDP growth rates ( $\Delta$ GDP), the adopted GDP growth targets are taken into account and taken into account the average annual consumer price index.

If we designate the current value of the tariff - (Tc), then the new admissible value of the tariff $(\mathrm{TN})$ will be determined by the expression:

$$
\mathrm{T}_{\mathrm{N}}=\frac{\mathrm{Tc}}{\mathrm{K}} \cdot \Delta \mathrm{T}
$$

where: Tc is the current tariff in current prices at the considered moment of time (X); K - a coefficient characterizing how much the ratio of the current tariff in 
current prices to the base year (for example, 2009) exceeded the growth of real GDP over the same time. In other words, the coefficient $(\mathrm{K})$ characterizes to what extent the "deviation" of the tariff growth at current prices from the real GDP growth has occurred:

$$
K=\frac{\Delta \mathrm{T}_{\mathrm{c}}}{\Delta \mathrm{GDP}}
$$

Here: $\Delta \mathrm{Tc}$ is the change in the value of the current tariff in relation to the value of the tariff in the base year, in relative units; $\Delta$ GDP - change in real GDP relative to the base year, in relative units.

In [6], the ratio $(\mathrm{Tc} / \mathrm{K})$ is called the calculated (base) tariff, those:

$$
\mathrm{T}_{\mathrm{b}}=\frac{\mathrm{Tc}}{\mathrm{K}}
$$

Formula (6) in view of (8) will take the following form:

$$
\mathrm{T}_{\mathrm{N}}=\mathrm{T}_{\mathrm{b}} \cdot \Delta \mathrm{T} \text {. }
$$

In formula (9), the value $(\Delta T)$ is the maximum allowable (allowable from the point of view of sustainable development of the economy) level of tariff increase, determined in relative units at the considered time (X) - (year or month) in relation to the estimated value of the tariff $(\mathrm{Tb}$.).

The value $(\Delta T)$ in case of growth (GDP) will be positive, and in the case of decrease (GDP) - negative.

In the case of growth (GDP) value $(\Delta T)$ can be determined by the expression, which will have the following form:

$$
\Delta \mathrm{T}=\Delta \mathrm{GDP}^{\prime} \cdot \alpha \cdot \frac{1}{I p c},
$$

where: $\Delta \mathrm{GDP}^{\prime}$ is a quantity characterizing the rate of change real (GDP) at the considered time point (X), (year or month), i. e., the index of change in GDP, in relative units.

In the absence of data $\left(\triangle \mathrm{BB} \Pi^{\prime}\right)$ at the considered time $(\mathrm{X})$, its value should be determined by the forecast based on the data of change (GDP) in the previous confidence period of time.

Practice shows that official data of the Bureau of Statistics publishes $1-1.5$ years behind. If the decision to change the tariff needs to be taken at the current time, then ( $\left.\Delta \mathrm{GDP}^{\prime}\right)$ must be predicted.

For this purpose, it is convenient to use the derivative of the main function of real (GDP) change over years for a certain number of years (for example, over the last $n=10$ years, since 2009 GDP $=\mathrm{Y}(\mathrm{Xi}), \mathrm{i}=1 \div \mathrm{n}$ and take for a given time (year or month $\mathrm{Xi}$ ) the first derivative $\left(\mathrm{Y}^{\prime}\right)$ of this function. This will be the change $\left(\Delta \mathrm{GDP}^{\prime}\right)$ at a given point in time (Xi), that is, the index of change in GDP.

The expression of the function reflecting the trend of real GDP change is shown in Figure 1 as an example. It has the following form for the accepted source data:

$$
\mathrm{Y}=0,0003 \cdot \mathrm{X}^{3}-0,0048 \cdot \mathrm{X}^{2}+0,0737 \cdot \mathrm{X}+0,9342 .
$$

The first derivative of function (11) will have the form:

$$
\begin{gathered}
\Delta \mathrm{GDP}^{\prime}(\mathrm{X})= \\
\mathrm{Y}^{\prime}=0,0003 \cdot 3 \cdot \mathrm{X} 2-0,0048 \cdot 2 \cdot \mathrm{X}+0,0737 .
\end{gathered}
$$

The above formula (10) includes the coefficient (a). It reflects the planned directive of economic development in the form of a planned level of GDP growth.

The coefficient (a) in our case is conveniently expressed as:

$$
\alpha=\frac{1}{\mathrm{~A}}
$$

where A is the coefficient of GDP growth ahead of schedule, planned, for example, in the Republic of Moldova until 2020 and established by the Law of the Republic of Moldova No. 166 dated 07/07/2012 "On approval of the National Development Strategy Moldova 2020" [7]. In the baseline scenario, an average annual growth rate of GDP until 2020 is estimated at $4.7 \%$, i. e. in relative units $\mathrm{A}=1.047$.

In formula (10), the average annual consumer price index (Ipc) is also taken into account, which is called the Inflation Rate. Its values are given above in table 1 and in figure 2 . This ratio varies in the range of $104 \div 109 \%$ or $1.04 \div 1.09$ in rel. units

Expression (9), reflecting the new value of the tariff (maximum allowable, allowable), taking into account (7-10) will take the following form:

$$
\mathrm{T}_{\mathrm{N}}=\frac{\mathrm{T}_{c} \cdot \Delta \mathrm{GDP} \prime}{\mathrm{K} \cdot \mathrm{A} \cdot I_{p c}}
$$

Where

Tc - the current value of the tariff in monetary units; $\triangle$ GDP ' is the growth index ("increments") of real GDP, in relative units at the considered time point; $\mathrm{K}$ - coefficient of "deviation" of the tariff, expressed by the formula (7); A planned GDP growth rate, in rel. unit; Ipc _ - the average annual consumer price index, in rel. units

Using this methodology, as well as the above data, further calculations were made of the marginal levels of increase in tariffs for major energy resources.

\section{The Results of the Calculation of the Maximum Levels of Tariff Increases Using National Accounts Data}

The calculation of permissible (allowable) levels of increase in tariffs for the types of energy under consideration was made using the formula (14) for the period of the end of 2018 - the beginning of 2019. The calculation of the maximum levels of the tariff for thermal energy was performed in [6].

For the wholeness of consistency, the results of these calculations are partially recalculated.

According to the above methodology, the calculation of the maximum allowable tariffs for the energy resources under consideration was made in tabular form (Table 4). 
Table 4. Calculation of the maximum permissible values of tariffs for natural gas, electric and thermal energy, at the beginning of 2019.

\begin{tabular}{|c|c|c|c|c|c|}
\hline № & Estimated values & Units & Natural gas & Electricity & Thermal energy \\
\hline 1 & 2 & 3 & 4 & 5 & 6 \\
\hline \multirow{4}{*}{1.} & Current Tariff (Tc): & & & & \\
\hline & Natural Gas & lei/1000 $\mathrm{m}^{3}$ & 4949 & - & - \\
\hline & Electricity & bani / kWh & - & 189,9 & - \\
\hline & Thermal energy & lei / Gcal & - & - & 1122 \\
\hline 2. & $\begin{array}{l}\text { The real GDP growth index (equation (12)): } \\
\Delta \mathrm{BB} \Pi^{\prime}(\mathrm{X})=\mathrm{Y}^{\prime}(\mathrm{X})=0.0003 \cdot 3 \cdot \mathrm{X} 2-0.0048 \cdot 2 \cdot \mathrm{X}+0.0737 \text { at } \mathrm{X}=10\end{array}$ & $\begin{array}{l}\% \\
\text { rel. units }\end{array}$ & $\begin{array}{l}6,77 \\
1,0677\end{array}$ & $\begin{array}{l}6,77 \\
1,0677\end{array}$ & $\begin{array}{l}6,77 \\
1,0677\end{array}$ \\
\hline 3. & Tariff growth in relation to the base (2009) year (tab. 3) & rel. units & 1,496 & 1,717 & 2,077 \\
\hline & Real GDP growth relative to the base (2009), forecast for the beginning of & & & & \\
\hline 4. & $\begin{array}{l}2019 \text { according to equation (11): } \\
\Delta \mathrm{GDP}(\mathrm{X})=\mathrm{Y}(\mathrm{X})=0.0003 \cdot \mathrm{X} 3-0.0048 \cdot \mathrm{X} 2+0.0737 \cdot \mathrm{X}++0.9342(\text { at } \mathrm{X}=10)\end{array}$ & rel. units & 1,4913 & 1,4913 & 1,4913 \\
\hline 5. & $\begin{array}{l}\text { The coefficient of "deviation" of tariff growth from the growth of real GDP, } \\
\text { (K) (P3 / P4) }\end{array}$ & rel. units & 1,066 & 1,2238 & 1,48 \\
\hline 6. & Planned GDP growth rate, $(\mathrm{A})$ & rel. units & 1,047 & 1,047 & 1,047 \\
\hline 7. & $\begin{array}{l}\text { The average annual consumer price index (Ipc), according to the equation in } \\
\text { Figure } 2 \text { (forecast) }\end{array}$ & rel. units & 1,0772 & 1,0772 & 1,0772 \\
\hline 8. & $\begin{array}{l}\text { The new value of the maximum allowable tariff }(\mathrm{TN}) \text { according to the } \\
\text { formula }(14) \text { : } \\
\text { - natural gas } \\
\text { - electricity } \\
\text { - thermal energy }\end{array}$ & $\begin{array}{l}\text { lei } / 1000 \mathrm{~m}^{3} \\
\text { bani/ } \mathrm{kWh} \\
\text { lei/ Gcal }\end{array}$ & 4671,6 & 156,13 & 762,85 \\
\hline 9. & $\begin{array}{l}\text { The necessary reduction in the value of the tariff in relation to the current } \\
\text { value (at the beginning of 2019) }\end{array}$ & $\%$ & 5,6 & 17,78 & 32,0 \\
\hline
\end{tabular}

\section{Results Analysis}

The results show that the current tariffs for energy resources are too high compared to the maximum allowable rates, which are determined based on the analysis of the dynamics of real GDP growth. The growth of tariffs substantially outpaces the growth of real GDP. Such a situation can hardly be considered normal. Similarly to the faster growth of tariffs for energy resources, there is an uncoordinated increase in tariffs for materials and services in the sphere of production, due to other sectors of the economy.

All this is a destabilizing factor constraining the growth of indicators of the economy, in general. This is primarily reflected in the volume of GDP, since tariffs increase the volume of Intermediate Consumption (IC), which is accompanied by a decrease in Gross Value Added (GVA) and, accordingly, GDP. The data in table 4 show that to meet the conditions coordinating the growth of tariffs with the growth of real GDP, tariffs should be lowered at the beginning of 2019:

- for natural gas - by $5.6 \%$;

- for electricity - by $17.7 \%$;

- for heat energy - by $32 \%$.

In the future, in the case of steady growth in real GDP, energy tariffs can be increased accordingly.

Their new level can be calculated by the method described in this article, as well as in [4-6].

\section{Conclusion}

It has been established that tariffs for energy resources, as well as for other types of material resources and services in the production sector, constitute the bulk of the volume of Intermediate Consumption (IC). It is shown that the higher the volume of Intermediate Consumption (IC), the smaller the volume of Gross Value Added (GVA) and, accordingly, the smaller the volume of Gross Domestic Product (GDP). On the example of indicators of the economy of the Republic of Moldova, using the National Accounts Data, calculations were made of changes in real GDP over the past ten years, from 2009 , taken as the base year, to 2018 , as well as the forecast for 2019. It was established that the volume of real GDP by 2017 compared with 2009 increased by 1.403 times. For the period of the beginning of 2019, real GDP growth is expected according to the forecast by 1.49 times compared to 2009.

Based on the available data, an analysis of changes in tariffs for the main types of energy resources was performed:

- for natural gas, for electricity and for thermal energy over the last ten years, since 2009.

The calculations used the current weighted average tariffs at current prices. The increase in tariffs by the beginning of 2019 compared to their values in 2009 was:

- to natural gas 1,496 times;

- for electricity - 1.717 times;

- for thermal energy - 2.077 times

In order to equalize the growth rate of tariffs for the type of energy resources under consideration with the growth rate of real GDP, and also to take into account the planned GDP growth rate and the average consumer price index, the following reductions in effective tariffs are necessary:

- for natural gas - by $5.6 \%$;

- for electricity - by $17.7 \%$;

- for heat energy - by $32 \%$.

The proposed method of setting the maximum permissible 
tariff levels can be recommended, as universal, in relation not only to energy resources, but also to tariffs for various types of materials and services in the production sector of the country's economy. The method allows to take into account the planned indicators of GDP growth, as well as the average annual consumer price index. In addition, the methodology can be used to coordinate the development of industries of the country or individual regions.

\section{References}

[1] Conturi Naţionale 2017. Biroul Naţional de Statistica al Republicii Moldova. Chişinău, 2018, 70 c.

[2] Conturi Naţionale 2014. Biroul Naţional de Statistica al Republicii Moldova. Chişinău, 2015.

[3] V. Leontiev. Economic essays. Theories, research, facts and politics. Per. From English - M.: Politizdat, 1990. Leontiev V. V. [Economicheskiye esse, Teorii, issledovanya, fakty I politika]. Per. s angl. - M.: Politizdat, 1990.

[4] V. Postolati. The method of determining the limits of possible increase in tariffs for energy resources and other material costs in the sectors of the economy of the Republic of Moldova, based on the analysis of indicators of National Accounts In: Problemele Energeticii Regionale nr. (32) 2016, p. 111-125.

[5] G. Duca, V. Postolati, M. Tîrşu, M. Grodeţki, A. Stratan, T. Gutium. Un model nou de stabilire a tarifelor în Energetică, Economie şi servicii. Academos, nr. 2 (45), 2017, p. 36-42.

[6] Postolatiy V., Babich V. Tariff Policy in the Formation of the Price of Thermal Energy. Institute of Power Engineering, Chisinau, Republic of Moldova. Problemele Energeticii Regionale. 3(38) 2018, p. 169-180.

[7] LAW of the Republic of Moldova Nr. 166 of July 11, 2012, on the approval of the Moldova 2020 national development strategy. [ZAKON Respubliki Moldova Nr. 166 ot 11.07.2012, ob utverzhdenii Natsional'noy strategii razvitiya «Moldova-2020».]
[8] Gametsky A. F. Solomon D. I. Mathematical modeling of macroeconomic processes. Chisinau, Eureka, 1997, 268p. Gametskiy A. F. Solomon D. I. Matematicheskoye modelirovaniye makroekonomicheskikh protsessov. Kishineu, «Yevrika», 1997, 268s.

[9] M. A. Gritsai. Brief notes on the stages of development of economics. Collection of works of the Laboratory of Electricity of the Institute of Energy. Issue 9, Chisinau, 2017. P. 148-156. M. A. Gritsay. Kratkiye zametki ob etapakh razvitiya ekonomicheskoy nauki. Sbornik trudov Laboratorii upravlyayemykh elek-troperedach Instituta energetiki. Vypusk 9, Kishinev, 2017. S. 148-156.

[10] THE NATIONAL REGULATORY AGENCY FOR ENERGY REGULATION. DECISION NO. 109 of March 17, 2017, regarding the tariffs for thermal energy delivered to the consumers by S. A. "Termoelectrica".

[11] THE NATIONAL REGULATORY AGENCY FOR ENERGY DECLARATION Nr. 232 of 16.09.2016 on the tariffs for thermal energy delivered to consumers by $\mathrm{S}$. A. "Termoelectrica".

\section{Biography}

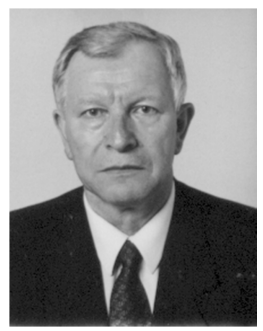

Vitaly Postolati, Doctor-habilitat of Technical Sciences, Academician of the Academy of Sciences of Moldova, Head of the Laboratory of Controlled Transmission of the Institute of Power Engineering of the Republic of Moldova. Research interests: large energy systems, system research, controlled flexible compact power transmissions, modern means of regulation, environmental and Energy security, energy economics, electric power, heat and power, renewable energy sources. 